\title{
The Relationship of Osteoprotegerin with Cardiovascular Risk Factors in Women with and Without Polycystic Ovary Syndrome
}

\author{
Polikistik Over Sendromu ve Kontrol Grubu Hastalarda Osteoprotegerin ve \\ Kardiyovasküler Risk Faktörleri Arasındaki ilişki \\ ๑ Gültekin Adanaş Aydın, ๑ Hilal Gülsüm Turan Özsoy* \\ Bursa Yüksek Ihtisas Training and Research Hospital, Clinic of Gynecology and Obstetrics, Bursa, Turkey \\ *Bursa Çekirge Public Hospital, Clinic of Radiology, Bursa, Turkey
}

Abstract

Aim: In this study, we aimed to compare osteoprotegerin (OPG) levels in patients with and without polycystic ovary syndrome (PCOS) and to investigate the correlation between OPG levels and cardiovascular risk factors.

Methods: A total of 49 patients with PCOS and 31 age- and body mass index-matched healthy controls were included in the study. Blood samples were collected and hormonal and metabolic parameters and OPG levels were analyzed. The carotid intima-media thickness (CIMT) was measured for each patient and control through ultrasonography.

Results: The low-density lipoprotein and total cholesterol levels were higher and the Homeostasis Model Assessment-Insulin Index (HOMA-IR) values were higher in patients with PCOS $(p=0.002, p=0.037$, and $p=0.028$, respectively). The OPG levels were $4.29 \mathrm{pmol} / \mathrm{L}$ and $4.07 \mathrm{pmol} / \mathrm{L}$ in the patient and control groups, respectively, indicating no significant difference between the groups. The CIMT was 0.57 in both groups.

Conclusion: Our study results suggest that OPG levels appear to be similar in patients with PCOS and healthy controls. Although OPG has been associated with endothelial dysfunction, atherosclerosis and coronary calcification in previous studies, currently not a useful marker for cardiovascular risk analysis in this patient population.

Keywords: Osteoprotegerin, polycystic ovary syndrome, atherosclerosis
Amaç: Bu çalışmada amacımız, polikistik over sendromu tanısı olan ve olmayan hastalarda osteoprotegerin (OPG) düzeylerinin karşılaştııılması ve OPG düzeylerinin kardiyovasküler risk faktörleri ile ilişkisinin araştırılmasıdır.

Yöntemler: Çalışmaya, aynı yaş ve vücut kitle indeksine sahip 49'u polikistik over sendromu ve 31'i kontrol grubunda olmak üzere toplam 80 hasta alındı. Hastalardan alınan kan örneklerinde, hormonal ve metabolik parametreler ile OPG düzeyleri değerlendirildi. Ultrasonografi ile her hastanın karotis arteri intima media kalınlığı ölçüldü.

Bulgular: Biyokimyasal testler incelendiğinde, düşük dansiteli lipoprotein ve kolesterol düzeyleri ile homeostasis model assessment insulin indeks düzeyleri polikistik over grubunda daha yüksek bulundu ( $p=0,002, p=0,037, p=0,028)$. OPG düzeyi, polikistik over grubunda 4,29 pmol/L, kontrol grubunda ise 4,07 pmol/L saptandı. Her iki grupta karotis intima media kalınlığı $0,57 \mathrm{~mm}$ olarak ölçüldü.

Sonuç: Çalışmada polikistik over grubu ile kontrol grubu arasında OPG düzeyleri ve karotis intima- media kalınlıkları açısından fark bulunmadı. Ayrıca OPG düzeyleri ile kardiyovasküler risk faktörleri arasında da bir bağlantı saptanmadı.

Anahtar Sözcükler: Osteoprotegerin, polikistik over sendromu, ateroskleroz
Address for Correspondence/Yazışma Adresi: Gültekin Adanaş Aydın, Bursa Yüksek Ihtisas

Training and Research Hospital, Clinic of Gynecology and Obstetrics, Bursa, Turkey E-mail: gadanas@gmail.com ORCID: orcid.org/0000-0002-9113-9846

Received/Geliş Tarihi: 31 December 2019 Accepted/Kabul Tarihi: 18 May 2020
${ }^{\circ}$ Copyright 2020 by The Medical Bulletin of istanbul Haseki Training and Research Hospital The Medical Bulletin of Haseki published by Galenos Yayinevi ${ }^{8}$ TTelif Hakkı 2020 istanbul Haseki Eğtitim ve Araş̧ırma Hastanesi Haseki Tip Bülteni, Galenos Yayinevi tarafindan yaynlanmış̧tr. 


\section{Introduction}

Polycystic ovary syndrome (PCOS) is characterized by chronic ovulatory dysfunction, clinical and/or biochemical hyperandrogenism, and polycystic ovary morphology. It is the most common endocrine disorder, affecting $5-8 \%$ of women of reproductive age (1). In patients with PCOS, insulin resistance (2), impaired glucose tolerance (3), type 2 Diabetes Mellitus (DM) (3), obesity (2), and dyslipidemia (4), which increase the cardiovascular (CV) risk, are frequently seen. In addition to well-known risk factors, an increase in the new risk factors, such as subclinical atherosclerosis and increased inflammatory response, has been shown (5).

A dramatic increase in CV diseases, particularly atherosclerosis, has been estimated worldwide by 2020 (6). Currently, there is an unmet need for identifying patients at high risk for CV diseases and for developing early diagnostic and therapeutic tools.

Some studies exploring the potential diagnostic biomarkers for $\mathrm{CV}$ diseases have been focused on the tumor necrosis factor (TNF) family (7). Receptor activator of nuclear factor kappa-B (RANK), RANK ligand (RANKL), and osteoprotegerin (OPG) are recent biomarkers which have been shown to play a role in vascular remodeling and atherosclerosis (8), and are members of the TNF receptor family. In vitro studies have demonstrated that OPG was expressed in arterial smooth muscle cells (9), pulmonary artery smooth muscle cells (10), WeibelPalade bodies of the endothelial cells (11), and alpha granules of megakaryocytes. RANK-RANKL is responsible for controlling osteoclast resorption and bone destruction, while OPG acts as a decoy receptor and inhibits cellular apoptosis, interacting with TNF-related apoptosis inducing ligand (TRAIL) (12). OPG is thought to play a role in endothelial cell function, angiogenesis, and vasculogenesis (7). In vitro studies have shown that it leads to vascular and endothelial changes seen in atherosclerosis by increasing apoptosis, inflammatory cell chemotaxis, and the release of matrix metalloproteinases (7). Several studies have shown that OPG induced endothelial inflammation (13) and led to proliferation of endothelial smooth muscle cells (14), resulting in subclinical atherosclerosis. In addition, OPG has been associated with endothelial dysfunction, atherosclerosis, and coronary calcification (15-17). Given its effects on endothelial dysfunction, it has been suggested that OPG might have a predictive value in the detection of metabolic syndrome and CV diseases (18).

In the present study, we aimed to compare OPG levels in patients with and without PCOS and to investigate the correlation between OPG levels and CV risk factors.

\section{Methods}

This cross-sectional study was carried out between March 2018 and June 2018. Written informed consent was obtained from each participant. The study protocol was approved by the Ethics Committee (2011-KAEK-25 2018/05-25).

The study was conducted in accordance with the principles of the Declaration of Helsinki.

A total of 49 patients with PCOS and 31 age- and body mass index (BMI)-matched healthy controls (overweight) were included in the study. In the patient group, PCOS was diagnosed based on the following Rotterdam criteria: 1) oligo-ovulation or anovulation, 2) clinical and/or biochemical signs of hyperandrogenism, and 3) polycystic ovaries on ultrasonography (USG) (19). The control group consisted of healthy individuals in whom no clinical, laboratory, and USG signs of PCOS were present. Exclusion criteria were as follows: history of diabetes, hyperprolactinemia, Cushing syndrome, congenital adrenal hyperplasia, thyroid disorders, and hypertension. Patients who received oral contraceptives, anti-androgens, aspirin, statin, and insulin-sensitizing agents within the past six months were also excluded.

\section{Biochemical Analyses and Hormone Assays}

Blood specimens were collected for biochemical and hormone analyses in the early follicular phase (between day 2 and day 5 of the menstrual cycle) between 8.00 and 10.00 a.m. after an overnight fast of at least 12 hours.

Follicle-stimulating hormone (FSH), luteinizing hormone $(\mathrm{LH})$, estradiol $\left(\mathrm{E}_{2}\right)$, total testosterone, dehydroepiandrosterone sulfate (DHEA), insulin, and 17-hydroxyprogesterone (17-OHP) were analyzed. In addition, fasting blood glucose, total cholesterol, low-density lipoprotein (LDL), high-density lipoprotein (HDL), and triglyceride (TG) were evaluated. Insulin resistance was calculated using the Homeostasis Model Assessment-Insulin Resistance (HOMA-IR) formula (fasting glucose $(\mathrm{mg} / \mathrm{dL}) \times$ fasting insulin $(\mu \mathrm{U} / \mathrm{mL}) / 405)$. Blood specimens were aliquoted and serum was isolated for OPG analysis and kept at $-30{ }^{\circ} \mathrm{C}$ until analysis. Serum OPG levels were analyzed using the Biovendor enzymelinked immunosorbent assay (ELISA). The assay detects both monomeric and dimeric forms of OPG, including OPG bound to its ligand.

\section{Anthropometric Measurements}

Body weight, height, and BMI were calculated for each participant. Waist circumference was measured at the narrowest part between the lower border of the rib cage and the iliac crest, while hip circumference was measured at the greater trochanter with the subject standing erect. 


\section{Carotid Intima-media Thickness Measurement}

The carotid intima-media thickness (CIMT) was defined as the average of the three thickness measurements between the intimal and medial-adventitial interfaces and was measured in the supine position with head flexion. CIMT measurements were performed by an experienced radiologist.

\section{Statistical Analysis}

Statistical analysis was performed using the SPSS version 18 software (SPSS Inc., Chicago, IL, USA). Descriptive data were expressed in mean \pm standard deviation, number, and frequency (\%). The Shapiro-Wilk test was used to test for normality in both PCOS and control groups. Systolic and diastolic blood pressures, 17-OHP, insulin, HOMA-IR, HDL, and TG showed nonnormal distribution in both groups, while the remaining variables showed normal distribution in at least one group. The independent samples t-test was used to compare the normally distributed variables between the groups, while the Mann-Whitney $U$ test was used to compare the non-normally distributed variables between the groups. Multiple covariance analysis was performed to evaluate the effect of PCOS and other variables on OPG, and PCOS was included in the model as a covariate to evaluate the effect of PCOS thoroughly and its effects were eliminated. Pearson's correlation coefficient was used to analyze the correlation between OPG and other variables between the groups. A p value of $<0.05$ was considered statistically significant.

\section{Results}

A total of 49 patients with PCOS and 31 healthy controls were included in the study. There was no significant difference in age, $\mathrm{BMI}$, and smoking status between the groups $(p=0.131, p=0.755$, and $p=0.981$, respectively). For the anthropometric measurements, the waist and hip circumferences and waist-to-hip ratio were statistically significantly higher in patients with PCOS ( $p=0.002, p=0.004$, and $p=0.016$, respectively).

For hormone analysis, thyroid-stimulating hormone, prolactin, $\mathrm{FSH}$, and $\mathrm{E}_{2}$ were statistically significantly lower, while LH, total testosterone, DHEA, 17-OHP, and fasting insulin levels were higher in the PCOS group. For biochemical analysis, LDL and cholesterol levels were higher in the PCOS group ( $p=0.002$ and $p=0.037$, respectively). In addition, the HOMA-IR values were statistically significantly higher in the PCOS group, compared to the control group $(p=0.028)$. The OPG levels were $4.29 \mathrm{pmol} / \mathrm{L}$ and $4.07 \mathrm{pmol} / \mathrm{L}$ in the PCOS and control groups, respectively.

Table 1 shows the anthropometric measurements, biochemical and hormone analysis results, CIMT measurements, and OPG levels in both groups. As there were significant differences in many variables between the PCOS and control groups, the possible effect of OPG was further analyzed. The correlation between the OPG levels and other variables was also investigated (Table 2). There was no significant correlation between the OPG levels and other variables. The multiple covariance analysis also revealed no significant correlation between the groups $(p=0.551)$.

\section{Discussion}

Polycystic ovary syndrome, which is a complex condition characterized by elevated androgen levels and menstrual irregularities, usually affects women of reproductive age. It is also associated with metabolic disorders such as insulin resistance, dyslipidemia, and obesity. Metabolic dysfunction with advanced age may make PCOS to be a predisposing factor for coronary artery disease.

Although several studies have shown an increase in the CV biomarkers in PCOS patients, it is still unclear whether increased biomarkers have a predictive value for CV diseases. Recently, a number of studies have investigated the role of RANK, RANKL, and OPG in the pathogenesis of $\mathrm{CV}$ diseases. In recent studies, a correlation has been shown between OPG levels and subclinical atherosclerosis, CV morbidity and mortality $(20,21)$. Increased OPG levels have been also associated with unstable angina (22), acute myocardial infarction, and sudden coronary events (23). In our study, we also compared the OPG levels between patients with and without PCOS and investigated the correlation between the OPG levels and $C V$ risk factors.

In the literature, there are three studies investigating the correlation between OPG levels and PCOS. Abali et al. (24) examined the relationship of OPG levels with CIMT and brachial artery flow-mediated vasodilation (FMD) in women with PCOS, compared to BMI-matched ( $<25 \mathrm{~kg} / \mathrm{m}^{2} /$ normal weight) controls. The CIMT and FMD are useful indicators of subclinical atherosclerosis and endothelial dysfunction. The latter is a helpful predictor of atheromatous disease and coronary artery disease (25) with a higher prognostic value than conventional risk factors. The aforementioned authors found a difference of $0.07 \mathrm{~mm}$ in the CIMT measurements of the patient group compared to the control group. In addition, the FMD levels were lower in PCOS patients. These findings are consistent with the literature, suggesting an increased risk of CV diseases. Irrespective of CIMT and FMD levels, the OPG levels were higher in the patient group than in controls. However, they found no significant correlation between OPG levels and CV risk factors. 
In another study, Pepene et al. (26) examined the relationship of OPG levels with insulin resistance and FMD levels in overweight patients with PCOS. Different from the study of Abali et al. (24), the authors found lower OPG levels in patients with PCOS than in controls. This can be attributed to the OPG-lowering effect of excess androgens. In addition, an OPG level of $>2.65 \mathrm{pmol} / \mathrm{L}$ indicated severe endothelial dysfunction. In the aforementioned study, there was no significant difference in CIMT measurements between the groups and the CIMT was not associated with OPG levels. However, there was only a positive correlation between OPG levels and insulin resistance among the CV risk factors.
Furthermore, Escobar-Morreale et al. (27) found lower OPG levels in patients with PCOS compared to healthy controls. It is paradoxical to obtain lower OPG levels in PCOS women, as OPG has been shown to be associated with coronary artery disease and severity of the disease $(28,29)$. As suggested by Escobar-Morreale et al. $(27)$, it should be further examined whether OPG has a protective effect against atherosclerosis. In the aforementioned study, lower OPG levels were explained by the neutralization of the RANKL which is a strong predictor of CV diseases and progression of atherosclerotic lesions to unstable plaques. However, the authors found no significant difference in RANKL levels between PCOS women and controls.

\begin{tabular}{|c|c|c|c|c|c|c|c|}
\hline \multirow[t]{2}{*}{ Variable* $^{*}$} & \multicolumn{3}{|c|}{ Control group } & \multicolumn{3}{|c|}{ Pcos } & \multirow{3}{*}{$\begin{array}{l}\mathbf{p} \\
0.131\end{array}$} \\
\hline & $n$ & Mean & SD & $n$ & Mean & SD & \\
\hline Age (year) & 31 & 28.26 & 4.08 & 49 & 26.69 & 4.69 & \\
\hline Height (cm) & 31 & 158.81 & 17.22 & 49 & 162.06 & 5.63 & 0.223 \\
\hline Bodyweight (kg) & 31 & 65.77 & 15.01 & 49 & 75.5 & 15.85 & 0.008 \\
\hline BMI $\left(\mathrm{kg} / \mathrm{m}^{2}\right)$ & 31 & 30.07 & 30.62 & 49 & 28.68 & 5.41 & 0.755 \\
\hline Galleway score & 31 & 8.84 & 4.95 & 49 & 17.2 & 8.13 & 0.001 \\
\hline Waist circumference $(\mathrm{cm})$ & 31 & 83.16 & 12.47 & 49 & 92.29 & 11.84 & 0.002 \\
\hline Hip circumference (cm) & 31 & 103.68 & 9.87 & 49 & 110.8 & 10.78 & 0.004 \\
\hline Waist-to-hip ratio & 31 & 0.8 & 0.06 & 49 & 0.83 & 0.05 & 0.016 \\
\hline $\mathrm{TSH}(\mu \mathrm{U} / \mathrm{mL})$ & 31 & 2.22 & 1.37 & 49 & 1.74 & 0.78 & 0.047 \\
\hline PRL (ng/mL) & 31 & 19.58 & 8.73 & 49 & 15.39 & 7.92 & 0.029 \\
\hline $\mathrm{FSH}(\mathrm{mIU} / \mathrm{mL})$ & 31 & 5.82 & 1.6 & 49 & 4.85 & 1.43 & 0.006 \\
\hline LH (mIU/mL) & 31 & 4.23 & 1.44 & 49 & 5.87 & 3.72 & 0.007 \\
\hline Estradiol (pg/mL) & 31 & 45.24 & 24.32 & 49 & 36.04 & 12.54 & 0.029 \\
\hline Total testosterone & 30 & 1.1 & 0.34 & 48 & 1.3 & 0.39 & 0.03 \\
\hline DHEA $(\mu \mathrm{g} / \mathrm{dL})$ & 31 & 180.77 & 76.05 & 49 & 230.01 & 89.25 & 0.013 \\
\hline Fasting blood glucose $(\mathrm{mg} / \mathrm{dL})$ & 31 & 88.77 & 9.34 & 49 & 90.49 & 9.52 & 0.431 \\
\hline LDL (mg/dL) & 31 & 87.52 & 27.36 & 49 & 108.37 & 29.21 & 0.002 \\
\hline Cholesterol (mg/dL) & 31 & 165.13 & 30.59 & 49 & 180.98 & 33.7 & 0.037 \\
\hline CIMT (right mid) (mm) & 31 & 0.57 & 0.05 & 49 & 0.59 & 0.12 & 0.373 \\
\hline CIMT (left mean) & 31 & 0.57 & 0.06 & 49 & 0.56 & 0.08 & 0.645 \\
\hline CIMT (mean) & 31 & 0.57 & 0.05 & 49 & 0.57 & 0.08 & 0.644 \\
\hline OPG (pmol/L) & 31 & 4.07 & 1.47 & 49 & 4.29 & 1.41 & 0.505 \\
\hline Systolic TA* & 31 & 110 & 10.33 & 49 & 112.37 & 9.94 & 0.431 \\
\hline Diastolic TA* & 31 & 65.16 & 10.29 & 49 & 70.49 & 9.14 & 0.017 \\
\hline 17-OH prog* $(\mathrm{ng} / \mathrm{mL})$ & 31 & 0.45 & 0.53 & 49 & 1.22 & 0.89 & 0.001 \\
\hline İnsülin* $(\mu \mathrm{U} / \mathrm{mL})$ & 31 & 8.63 & 4.45 & 49 & 11.45 & 6.26 & 0.027 \\
\hline HOMA IR* & 31 & 1.93 & 1.12 & 49 & 2.63 & 1.64 & 0.028 \\
\hline $\mathrm{HDL}^{*}$ & 31 & 52.55 & 12.69 & 49 & 48.94 & 11.1 & 0.232 \\
\hline
\end{tabular}


Considering the relationship between OPG levels and $F M D$, it is still under question whether OPG produces response to endothelial injury or it has an effect in the pathogenesis of endothelial dysfunction. In humans, OPG appears to have a dichotomous role: in healthy individuals, it is in a fine balance with proatherogenic and antiatherogenic effects; however, in case of persistent positive induction by various risk factors, the proatherogenic pathway becomes predominant (11). In addition, OPG is an anti-apoptotic factor in endothelial cells and it leads to proliferation of the endothelial cells in micro-vessels (30). It has been shown that, in the presence of TNF, OPG increases the release of intercellular adhesion molecule-1, vascular cell adhesion molecule-1, and E-selectin (30). It also increases fibrosis in the vascular smooth muscles (31) and inhibits vascular calcification (32). Observational studies have demonstrated that OPG levels are positively associated with CV diseases but animal studies have also shown the protective role of OPG against CV diseases (33). Based on these findings, it still remains to be elucidated whether OPG is a pathogenic factor or an ineffective marker for $\mathrm{CV}$ diseases.
In the present study, our study groups had age and BMI similar to the study of Pepene et al. (26). We found higher OPG levels in women with PCOS than in controls; however, it did not reach statistical significance. In addition, LDL, total cholesterol, insulin, and HOMA-IR values, and diastolic blood pressure were significantly higher in patients with PCOS, although there was no relationship between the OPG levels and these risk factors. We also found similar CIMT measurements, an indicator of subclinical atherosclerosis, between the two groups and found no relationship between OPG levels and CIMT measurements.

In the literature, there is a controversy regarding the relationship between OPG levels and CV risk factors. Some authors have suggested that OPG was lower in patients with obesity than in healthy controls (34), while the others have shown no relationship between OPG levels and BMI $(35,36)$. In addition, increased OPG levels have been associated with elevated LDL and total cholesterol levels $(36,37)$, while some others have shown no relationship (36). Furthermore, some authors have shown a relationship between increased blood pressure and OPG levels, although the others have found no relationship (36-39).

\begin{tabular}{|c|c|c|c|c|c|c|}
\hline & \multicolumn{3}{|c|}{ Control group } & \multicolumn{3}{|c|}{ PCOS group } \\
\hline & \multicolumn{3}{|c|}{ OPG (pmol/L) } & \multicolumn{3}{|c|}{ OPG (pmol/L) } \\
\hline & $r$ & $\mathbf{P}$ & $\mathbf{n}$ & $r$ & $\mathbf{P}$ & $\mathbf{n}$ \\
\hline Age, year & -0.043 & 0.819 & 31 & -0.076 & 0.605 & 49 \\
\hline BMI, $\mathrm{kg} / \mathrm{m}^{2}$ & -0.193 & 0.298 & 31 & -0.253 & 0.079 & 49 \\
\hline Galleway score & -0.148 & 0.426 & 31 & 0.000 & 0.998 & 49 \\
\hline Waist-to-hip ratio & 0.067 & 0.721 & 31 & -0.011 & 0.942 & 49 \\
\hline SBP $(\mathrm{mmHg})$ & -0.130 & 0.486 & 31 & -0.117 & 0.423 & 49 \\
\hline DBP (mmHg) & -0.107 & 0.568 & 31 & -0.034 & 0.819 & 49 \\
\hline $\mathrm{TSH}(\mu \mathrm{U} / \mathrm{mL})$ & 0.095 & 0.609 & 31 & 0.144 & 0.322 & 49 \\
\hline PRL (ng/mL) & 0.099 & 0.594 & 31 & 0.204 & 0.159 & 49 \\
\hline $\mathrm{FSH}(\mathrm{mIU} / \mathrm{mL})$ & -0.230 & 0.213 & 31 & 0.186 & 0.201 & 49 \\
\hline LH (mIU/mL) & -0.147 & 0.430 & 31 & 0.109 & 0.456 & 49 \\
\hline Estradiol $(\mathrm{pg} / \mathrm{mL})$ & -0.046 & 0.804 & 31 & -0.051 & 0.729 & 49 \\
\hline Total testosterone & -0.043 & 0.822 & 30 & 0.043 & 0.774 & 48 \\
\hline DHEA $(\mu \mathrm{g} / \mathrm{dL})$ & 0.200 & 0.281 & 31 & 0.170 & 0.242 & 49 \\
\hline 17-OHP (ng/mL) & 0.411 & 0.022 & 31 & 0.150 & 0.303 & 49 \\
\hline HOMA-IR & 0.287 & 0.117 & 31 & -0.229 & 0.114 & 49 \\
\hline $\mathrm{HDL}(\mathrm{mg} / \mathrm{dL})$ & 0.044 & 0.813 & 31 & 0.108 & 0.459 & 49 \\
\hline LDL (mg/dL) & -0.021 & 0.909 & 31 & 0.010 & 0.944 & 49 \\
\hline TG (mg/dL) & 0.226 & 0.222 & 31 & 0.004 & 0.978 & 49 \\
\hline CIMT, mean (mm) & 0.101 & 0.590 & 31 & -0.002 & 0.990 & 49 \\
\hline \multicolumn{7}{|c|}{ 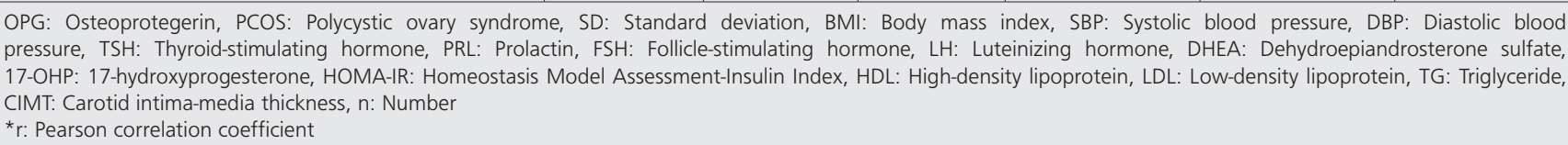 } \\
\hline
\end{tabular}


It is well-known that PCOS shares similar characteristics with metabolic disorders such as obesity, hyperlipidemia, insulin resistance, and increased inflammation. In a study, Bernardi et al. (40) reported increased OPG expression due to increased inflammatory response in patients with metabolic syndrome than in healthy individuals. However, there are studies showing no significant relationship between metabolic syndrome and OPG level (38).

CV diseases have a long subclinical phase and, therefore, certain markers are used for early diagnosis and early identification of high-risk patients. Previous studies mostly included younger women with PCOS and longterm follow-up is needed to identify CV diseases in this patient population.

\section{Study Limitations}

The cross-sectional design of our study is the main limitation. Another limitation is that we were unable to evaluate osteoporosis in our study population; however, the role of OPG in bone turnover is well-known. Nonetheless, we included younger patients and BMI-matched controls and those with low-risk for osteoporosis in our study. Finally, although we measured fasting blood glucose and insulin levels, we did not measure Hba1c levels, and thus no prediabetic patient was found and excluded from the study.

\section{Conclusion}

Our study results showed that there was no significant difference in OPG levels between patients with PCOS and healthy controls. We also found no significant relationship between OPG levels and CV risk factors. These findings suggest that OPG is, currently, not a useful marker for CV risk analysis in this patient population. Further large-scale and long-term studies including different phenotypes of PCOS are needed for better understanding of the role of OPG in CV diseases.

\section{Acknowledgments}

The authors gratefully thank to Hacer Ebru Açıkgöz, Şeyda Yalçınbayır and all Bursa Çekirge State Hospital, Biochemisty Laboratuary participians for their assistance and support.

\section{Authorship Contributions}

Concept: G.A.A., H.G.T.Ö. Design: G.A.A., H.G.T.Ö. Data Collection or Processing: G.A.A., H.G.T.Ö. Analysis or Interpretation: G.A.A., H.G.T.Ö. Literature Search: G.A.A., H.G.T.Ö. Writing: G.A.A.

Conflict of Interest: The authors declare no conflict of interests.

Financial Disclosure: The authors declared that this study received no financial support.

\section{References}

1. Azziz R, Woods KS, Reyna R, Key TJ, Knochenhauer ES, Yildiz BO. The prevalence and features of the polycystic ovary syndrome in an unselected population. J Clin Endocrinol Metab 2004;89:2745-9.

2. Diamanti-Kandarakis $E$, Dunaif $A$.Insulin resistance and the polycystic ovary syndrome revisited: an update on mechanisms and implications. Endocrine Reviews 2012;33:981-1030.

3. Moran LJ, Misso ML, Wild RA, Norman RJ. Impaired glucose tolerance, type 2 diabetes and metabolic syndrome in polycystic ovary syndrome: a systematic review and metaanalysis. Human Reproduction Update 2010;16:347-63.

4. Randeva HS, Tan BK, Weickert MO, et al. Cardiometabolic aspects of the polycystic ovary syndrome. Endocrine Reviews 2012;33:812-41.

5. Escobar-Morreale HF, Luque- Ramírez M, González F. Circulating inflammatory markers in polycystic ovary syndrome:a systematic review and metaanalysis. Fertility and Sterility 2011;95:1048-58.

6. Mozaffarian D, Benjamin EJ, Go AS, et al. Heart Disease and Stroke Statistics-2016 Update: A Report From the American Heart Association. Circulation 2016;133:e38-60.

7. Rochette L, Meloux A, Rigal E, Zeller M, Cottin Y, Vergely C. The Role of Osteoprotegerin and Its Ligands in Vascular Function.Int J Mol Sci 2019;6;20:705.

8. Kiechl S, Werner P, Knoflach M, Furtner M, Willeit J, Schett G. The osteoprotegerin/RANK/ RANKL system: a bone key to vascular disease. Expert Rev Cardiovasc Ther 2006;4:801-11.

9. Schoppet M, Kavurma M, Hofbauer LC, Shanahan CM. Crystallizing nanoparticles derived fromvascular smooth muscle cells contain the calcification inhibitor osteoprotegerin. Biochemical and Biophysical Research Communications 2011;407:103-7.

10. Lawrie A, Waterman E, Southwood M, et al. Evidence of a role for osteoprotegerin in the pathogenesis of pulmonary arterial hypertension. American Journal of Pathology 2008;172:256-65.

11. Zannettino ACW, Holding CA, Diamond $P$, et al. Osteoprotegerin (OPG) is localized to the Weibel-Palade bodies of human vascular endothelial cells and is physically associated with vonWillebrand factor. Journal of Cellular Physiology 2005;204:714-23.

12. Venuraju SM, Yerramasu A, Corder R, Lahiri A. Osteoprotegerin as a predictor of coronary artery disease and cardiovascular mortality and morbidity. Journal of theAmerican College of Cardiology 2010;55:2049-61.

13. Mangan SH, Van Campenhout A, Rush C, Golledge J. Osteoprotegerin upregulates endothelial cell adhesion molecule response to tumor necrosis factor-alpha associated with induction of angiopoietin-2. Cardiovasc Res 2007;76:494505.

14. Candido R, Toffoli B, Corallini $F$, et al. Human full-length osteoprotegerin induces the proliferation of rodent vascular 
smooth muscle cells both in vitro and in vivo. J Vasc Res 2010;47:252-61.

15. Shin JY, Shin YG, Chung CH. Elevated serum osteoprotegerin levels are associated with vascular endothelial dysfunction in type 2 diabetes. Diabetes Care 2006;29:1664-6.

16. Xiang GD, Sun HL, Zhao LS. Changes of osteoprotegerin before and after insulin therapy in type 1 diabetic patients. Diabetes Research and Clinical Practice 2007;76:199-206.

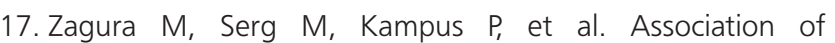
osteoprotegerin with aortic stiffness in patients with symptomatic peripheral artery disease and in healthy subjects. American Journal of Hypertension 2010;23:586-91.

18. Barbu CG, Arsene AL, Florea S, et al. Cardiovascular risk assessment in osteoporotic patients using osteoprotegerin as a reliable predictive biochemical marker. Mol Med Rep 2017; 16:6059-67.

19. Rotterdam ESHRE/ASRM-Sponsored PCOS consensus workshop group. Revised 2003 consensus on diagnostic criteria and long-term health risks related to polycystic ovary syndrome (PCOS). Hum Reprod 2004;19:41-7.

20. Lieb $W$, Gona $P$, Larson $M G$, et al. Biomarkers of the osteoprotegerin pathway: clinical correlates, subclinical disease, incident CVD and mortality. Arterioscler Thromb Vasc Biol 2010;30:1849-54.

21. Jono $S$, Ikari $Y$, Shioi $A$, et al. Serum osteoprotegerin levels are associated with presence and severity of coronary artery disease. Circulation 2002;106:1192-4.

22. Sandberg WJ, Yndestad A, Oie E, et al. Enhanced T-cell expression of RANK ligand in acute coronary syndrome: possible role in plaque destabilization. Arterioscler Thromb Vasc Biol 2006;26:857-63.

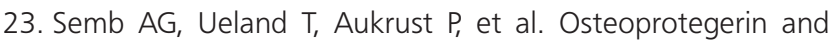
soluble receptor activator of nuclear factor-kappaB ligand and risk for coronary events: a nested case-control approach in the prospective EPIC-Norfolk population study 1993-2003. Arterioscler Thromb Vasc Biol 2009;29:975-80.

24. Abali R, Tasdemir N, Alpsoy S, et al. No relationship between osteoprotegerin concentrations and endothelial dysfunction in non-obese women with and without polycystic ovary syndrome. Arch Gynecol Obstet 2015;291:1075-80.

25. Gokce N, Keaney JF Jr, Hunter LM, Watkins MT, Menzoian JO, Vita JA. Risk stratification for postoperative cardiovascular events via noninvasive assessment of endothelial function: a prospective study. Circulation 2002;105:1567-72.

26. Pepene CE, Ilie IR, Marian I, Duncea I. Circulating osteoprotegerin and soluble receptor activator of nuclear factor kB ligand in polycystic ovary syndrome: relationships to insulin resistance and endothelial dysfunction. European Journal of Endocrinology 2011;164:61-8.

27. Escobar-Morreale HF, Botella-Carretero Jl, Martínez-García $M A$, et al. Serum osteoprotegerin concentrations are decreased in women with the polycystic ovary syndrome.Eur J Endocrinol 2008;159:225-32.

28. Jono S, Ikari $Y$, Shioi A, et al. Serum osteoprotegerin levels are associated with the presence and severity of coronary artery disease. Circulation 2002;106:1192-4.

29. Avignon A, Sultan A, Piot C, et al. Osteoprotegerin: a novel independent marker for silent myocardial ischemia in asymptomatic diabetic patients. Diabetes Care 2007;30:29349.

30. McGonigle JS, Giachelli CM, Scatena M. Osteoprotegerin and RANKL differentially regulate angiogenesis and endothelial cell function. Angiogenesis 2009;12:35-46.

31. Baud'huin M, Duplomb L, Teletchea S, et al.Osteoprotegerin: multiple partners for multiple functions. Cytokine and Growth Factor Reviews 2013;24:401-9.

32. Wright HL, McCarthy HS, Middleton J, Marshall MJ. RANK, RANKL and osteoprotegerin in bone biology and disease. Current Reviews in Musculoskeletal Medicine 2009;2:56-64.

33. Morony S, Tintut $Y$, Zhang et al Z. Osteoprotegerin inhibits vascular calcification without affecting atherosclerosis in Idlr(-/-) mice. Circulation 2008;117:411-20.

34. Holecki M, Zahorska-Markiewicz B, Janowska J, et al. The influence of weight loss on serum osteoprotegerin concentration in obese perimenopausal women. Obesity (Silver Spring) 2007;15:1925-9.

35. Gannage-Yared MH, Yaghi C, Habre B, et al. Osteoprotegerin in relation to body weight, lipid parameters insulin sensitivity, adipocytokines, and C-reactive protein in obese and nonobese young individuals: results from both cross-sectional and interventional study. Eur J Endocrinol 2008;158:353-9.

36. Victor RG, Haley RW, Willett DWL, et al. The Dallas Heart Study: A population-based probability sample for the multidisciplinary study of ethnic differences in cardiovascular health. J Am Cardiol 2004:1473-80.

37. Oh ES, Rhee EJ, Oh KW, Lee WY, Baek KH, Yoon KH. Circulating osteoprotegerin levels are associated with age, waist-to-hip ratio, serum-total cholesterol, and low-density lipoprotein cholesterol levels in healthy Korean women. Metabolism 2005;54: 49-54.

38. Gannage-Yared MH, Fares F, Semaan M, Khalife S, Jambart S. Circulation osteoprotegerin is correlated with lipid profile, insulin sensitivity adiponectin and sex steroids in an ageing male population. Clin Endocrinol 2006;64:652-8.

39. Browner WS, Lul LY, Cumming SR. Association of serum osteoprotegerin levels with diabetes, stroke, bone density, fractures, and mortality in elderly women. J Clinic Endocrinol Metab 2001;86:631-7.

40. Bernardi S, Fabris B, Thomas M, et al. Osteoprotegerin increases in metabolic syndrome and promotes adipose tissue proinflammatory changes. Mol Cell Endocrinol 2014;394:1320. 